\title{
Risk Management Planning for Agricultural Business Owners ${ }^{1}$
}

\author{
Martie Gillen and Beatrice Pierre ${ }^{2}$
}

The Southeastern Coastal Center for Agricultural Health and Safety (SCCAHS) is part of a Centers for Disease Control and Prevention (CDC)/National Institute for Occupational Safety and Health (NIOSH) Agricultural Health and Safety Initiative. SCCAHS explores and addresses the occupational safety and health needs of people working in agriculture, fishing, and forestry in Alabama, Florida, Georgia, Mississippi, North Carolina, South Carolina, the U.S. Virgin Islands, and Puerto Rico.

The University of Florida is the lead institution of this Center, partnering with the University of South Florida (USF), Florida State University (FSU), Florida A\&M University (FAMU), Emory University, and the University of the Virgin Islands. These universities are working together on a range of interdisciplinary research and educational projects designed to promote occupational health and safety among the 240,000 farms - estimated by the U.S. Department of Agriculture-to be operating in the region, their operators, families, employees, and contractors, as well as those in the forestry and fishery industries.

Risk identification is the beginning point for risk management planning because solution identification begins with knowledge of the problem. Five main types of risk should be evaluated: production risk; price or market risk; financial risk; legal risk; and human risk.

\section{General Risk: Questions for Consideration}

1. Do you have a confident relationship with your risk management advisors?

2. Are you able to evaluate new technologies?

3. Are you planning for your dependents' educational needs? Are these savings protected?

4. Does your savings plan align with your retirement plans?

5. Do family members know the location of all important documents?

6. Do you have the knowledge and skills to assess all areas and levels of risk?

7. Are you constantly looking for ways to increase profitability?

Production risk derives from the uncertain natural growth processes of crops and livestock. Weather, diseases, pests, and other factors affect both the quantity and quality of commodities. Listed below are ways to alleviate some of the risk.

- Control or minimize risk through management practices (Crane, Gantz, Isaacs, Jose, \& Sharp, 2013). Practice preventative maintenance to minimize the likelihood of

1. This document is FCS3354, one of a series of the Department of Family, Youth and Community Sciences, UF/IFAS Extension. Original publication date August 2019. Visit the EDIS website at https://edis.ifas.ufl.edu for the currently supported version of this publication.

2. Martie Gillen, associate professor, Extension specialist, Department of Family, Youth and Community Sciences; and Beatrice Pierre, graduate student, Department of Family, Youth and Community Sciences; UF/IFAS Extension, Gainesville, FL 32611.

The Institute of Food and Agricultural Sciences (IFAS) is an Equal Opportunity Institution authorized to provide research, educational information and other services

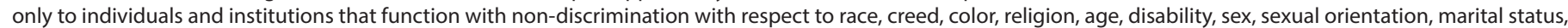

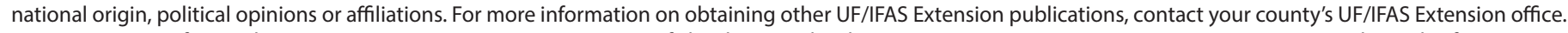
U.S. Department of Agriculture, UF/IFAS Extension Service, University of Florida, IFAS, Florida A \& M University Cooperative Extension Program, and Boards of County Commissioners Cooperating. Nick T. Place, dean for UF/IFAS Extension. 
negative events. Examples of preventative maintenance include the use of chemicals and fertilizer that may help stabilize production in both quantity and quality. Irrigation is effective in minimizing the effects of low rainfall or drought. Health and nutrition programs can help in livestock production.

- Reduce production variability by implementing changes such as diversifying, integrating, or applying new technology (Crane et al., 2013). Diversification can help farmers reduce income variability. Farmers should strive to maintain flexibility in the use of farm assets and operating procedures as a production response to variability. Vertical integration includes transferring the output from one stage of production to another. New technology refers to precision agriculture, which takes advantage of advances in computers and mechanical engineering to make better and more efficient machines and equipment.

- Transfer production risk by contracting or purchasing insurance (Crane et al., 2013). Risk may be transferred by contracting with another entity to combine various market functions. Insurance can also be used to transfer risks to an insurance company. Consider whether an adverse event is large or frequent enough to cause an economic hardship. There are three main types of insurances that all operators should typically have: property and casualty insurance; health, life, and disability insurance; and liability insurance.

\section{Production Risk: Questions for Consideration}

1. Have you recently evaluated your risk in the event of the loss of your crops?

2. Have you recently evaluated your risk in the event of the loss of your animals?

3. Have you investigated alternative production methods and their associated risk?

4. Do you have adequate knowledge to consider new technologies?

5. Is your crop insurance protection adequate to cover severe crop loss?

6. Have you reviewed a comprehensive listing of insurance options with your agent?

7. Have you conducted a Strengths, Weaknesses, Opportunities, and Threats (SWOT) analysis for your operation?
8. Are you located in an irrigation-compatible area?

Price or market risk results from uncertainty about the prices producers will receive for commodities or the prices they must pay for inputs. It varies from commodity to commodity. Tackling such a risk requires the elaboration of a marketing plan as part of the initial business plan. The marketing plan determines specific actions to be taken to accomplish the business goals. The marketing plan requires an understanding of the desired tools and alternatives, analysis of the alternatives, and discipline to follow through. There are six basic decisions with each marketing action (Crane et al., 2013):

- When to price or sell.

- Where to price or sell.

- What form, grade, or quality to sell.

- How to price.

- What services to utilize.

- When and how to deliver.

\section{Price or Market Risk: Questions for Consideration}

1. Do you have a current, written marketing plan?

2. Have you coordinated your marketing plan with your goals and objectives and your financial and production plans?

3. Managing marketing risks:

- Are you comfortable with your knowledge of marketing opportunities?

- Have you reviewed your marketing options within the past 6 months?

4. Do you understand how crop insurance revenue guarantees can enhance marketing opportunities?

Financial risks threaten the livelihood of a business. Examples of financial risk include: the cost and availability of debt capital; the ability to meet cash flow needs in a timely manner; the ability to maintain and grow equity; and the ability to absorb short-term financial shocks (Crane et al., 2013). Financial risk occurs when the farm business borrows money and creates an obligation to repay debt. Rising interest rates, the prospect of loans being called by lenders, and restricted credit availability are contributing factors to financial risk. There are four financial tools to manage financial risk: the balance sheet, commonly called a net worth statement; the income and expense statement, 
also known as a profit and loss statement; the owner's equity statement; and the cash flow statement (Olsen, 2012).

- The balance sheet is a snapshot of the financial position given a specific date. It shows the value of the business's assets as well as the value of all debts (liabilities), identified as the claims of others against the business, resulting in the net worth or the owner's claims against the business. Two sets of balance sheets may be maintained: market value of assets and cost values. The balance sheet is represented by the following equation: Total assets total liabilities $=$ net worth

- The income and expense statement shows the net income for the farm business for a specified period of time. It includes sales/revenues generated by the farm, the cost of goods sold, the gross profit, the operating expenses (administrative fees, salaries, utilities, depreciation on assets, gain or loss on capital assets), and the net income or loss.

Sales or revenues - cost of goods sold $=$ gross profit

Gross profit - operating expenses $=$ net profit or loss

- The statement of owner's equity links the beginning and ending balance sheets and the income statements for the year. It comprises the beginning capital invested in the business, any profit or loss incurred by the business for the year, and any additional investment or withdrawal made by stakeholders during the same year.

- The cash flow statement can be a statement of past activities or a budget of expected cash inflows and outflows. As a statement of past performance, a cash flow statement shows how and when cash was generated and used to pay for inputs, loan payments, family living, and any capital purchases. A projected cash flow is essential to evaluate the borrowing needs of a business and the feasibility of repayment plans. This process reconciles the two statements and shows the impact of the withdrawals for family living costs.

\section{Financial Risk: Questions for Consideration}

1.Do you have a current business plan?

2. Have you planned for a best-case scenario and developed a plan for how additional income will be used?

3. Have you planned for a worst-case scenario and considered an alternative plan?

4. Do you know your cost of production?
5. Do you know your break-even costs?

6. Do you have the knowledge to create a balance sheet, cash flow, and income statements?

7. Do you have the knowledge to interpret important financial ratios?

8. What is your debt-to-asset ratio?

9. Is the growth of your net worth exceeding?

10. Have you reviewed your ratio trends with your lender?

11. Is your crop insurance protection adequate to:

- Repay current operating loans?

- Allow you to take advantage of marketing opportunities?

12. Have you reviewed your tax liability within the past 3 months to determine your tax strategies?

13. Have you investigated all of your potential financing options?

14. Have you investigated existing government programs?

15. Have you considered the trade-offs between maintaining your current investments (certificates of deposit, savings, etc.) and/or reinvesting in expanding your own operation?

16. Do you consult a financial management consultant, lender, accountant, insurance provider, or other professional when making major financial decisions?

17. Are you comfortable with your level of debt?

Financial ratios related to risk factors are liquidity, solvency, profitability, and repayment capacity. Liquidity and solvency are based on data from the balance sheet. Profitability measures come from the income and expense statement, and repayment capacity comes from the cash flow statement. Liquidity measures how well a business can meet its financial obligations in the short run. It is expressed as the value of current assets divided by total short-term debts. The goal is a ratio greater than 1.7 (Crane et al., 2013). Solvency is the ability of a business to have enough assets to cover its total debt if all assets were sold. The lower a company's solvency ratio, the greater the probability that it will default on its debt obligations. The goal is a ratio greater than 30\% (Crane et al., 2013). 
Legal or institutional risks result from uncertainties related to individuals and/or groups including the government. Tax laws, regulations for chemical use, rules for animal waste disposal, and the level of price or income support payments are examples of government decisions that can have a major impact on the farm business. The legal issues most commonly associated with agriculture fall into five broad categories: contractual arrangements; business organization; laws and regulations; tort liability; and public policy and attitudes (Crane et al., 2013).

\section{Legal Risk: Questions to Consider}

1. Do you understand the provisions of all of your contracts, leases, and loans?

2. Have you recently evaluated all the different business entity options for your operation?

3. Do you have a working relationship with your attorney and accountant, and have you reviewed your goals and objectives with each?

4. Are you in compliance with regulations regarding worker protection, pesticide use records, vehicle registrations, and necessary safety inspections?

Human or personal risk refers to factors including problems with human health or personal relationships that can affect the farm business. Accidents, illness, death, and divorce are examples of personal crises that can threaten a farm business. Human risk can be divided into four main categories: human health and well-being; family and business relationships; employee management; and succession planning (Crane et al., 2013).

\section{Human Risk: Questions to Consider}

1.Is your personal insurance coverage current?

- Do you have adequate medical and disability insurance?

- Do you have adequate life insurance to cover your wishes and farm transfer at current values?

2. Have you calculated your risk exposure to employee accidents or dishonesty?

3. Have you provided all employees with comprehensive safety training?

4. Do you have an employee handbook?
5. Are your goals Specific, Measurable, Attainable, Reasonable, and Timed (SMART)?

6. Have you conveyed the goals and objectives of the business to all family members, business team members, and employees?

7. Are your goals written?

8. Is everyone in your family (or on your team) employed to the full extent of his or her education, training, and experience?

\section{References}

Crane, L., Gantz, G., Isaacs, S., Jose, D., \& Sharp, R. (2013). Introduction to Risk Management (Second Edition). Extension Risk Management Education and Risk Management Agency. http://extensionrme.org/pubs/introductiontoriskmanagement.pdf

Olsen, D. (2012). Farm Financial Guidelines and Ratios. Retrieved from https://www.ffsc.org/wp-content/uploads/2012/06/FarmFinancialGuidelinesRatios1.pdf 